\title{
Contemporary Chinese anthropology: reflections, developments and prospects
}

\author{
Shigang Liu ${ }^{1}$
}

Received: 21 July 2021 / Accepted: 10 August 2021 / Published online: 10 September 2021

(c) The Author(s) 2021

\begin{abstract}
Since the 16th World Congress of the International Union of Anthropological and Ethnological Sciences (IUAES) was successfully held in Kunming in July 2009, Chinese anthropologists have been committed to exploring the new direction of Chinese anthropology, striving to build the discipline system of Chinese anthropology in the new era, thus making it a prominent discipline in the study of contemporary Chinese society. After more than ten years' efforts, Chinese anthropologists have made great progress both in theory and practice, which is embodied in two aspects: the first one is interdisciplinary comprehensive researches and cross-cultural comparative researches based on the thinking and efforts of prestigious anthropologists such as Qiao Jian, Fei Xiaotong, and Li Yiyuan; the second one is the new direction and construction of discipline system of Chinese anthropology in the new era pursued by contemporary Chinese anthropologists. Over the past decades, significant achievements have been made in Chinese anthropology, especially in three aspects. The first is localization of anthropology with less dependency on Western theories and more self-dependence, so as to establish Chinese anthropological schools enjoying localized concepts and theories. The second is modernization of anthropology which demands more adaptability and less discipline inertia and calls for practical researches on current social topics and modernization transformation from the perspective of anthropology. The third is internationalization of anthropology to reduce discipline closeness by conducting overseas researches and exchanges, thereby strengthening international communication and cooperation.
\end{abstract}

Shigang Liu

napoleongang@163.com

1 China Academy of Social Management/ School of Sociology, Beijing Normal University, No.19, Xinjiekouwai St, Haidian District, Beijing 100875, China 
Keywords Chinese anthropology · New development · Discipline system · Localization $\cdot$ Modernization $\cdot$ Internationalization

\section{Introduction}

At present, with the continuous development of the reform and opening up, China's economic and social structure is in a huge transformation. Chinese society is transforming from an agricultural society to an industrial society, and from a planned economy to a socialist market economy. In the face of this great change, Chinese anthropologists deeply realize that the current anthropological theories and research methods cannot effectively explain the current transformation of Chinese society. Then, how to develop Chinese anthropology in the transitional period, or how to explore the new direction of the development of anthropology with Chinese characteristics, and make it become a prominent discipline, have become the missions of contemporary Chinese anthropologists. In recent years, many scholars have begun to explore the new direction of the development of Chinese anthropology, trying to help anthropology walk out of the dilemma of traditional rural and community research, and bring anthropology research into the grand narrative of China's current economic and social structure transformation, so as to avoid the marginalization crisis again.

\section{Reflections: thoughts of prestigious Chinese anthropologists}

Since anthropology was introduced into China more than 100 years ago, Chinese scholars have been exploring the localization or sinicization of anthropology. Generations of Chinese anthropologists have made arduous efforts to find the right ways. From the first generation of Chinese anthropologists, such as Prof. Wu Wenzao, Prof. Lin Huixiang, Prof. Pan Guangdan, etc., to the sixth generation of contemporary anthropologists, such as Prof. Wang Mingming, Prof. Gao Bingzhong, Prof. Ma Guoqing, Prof. Wang Yanzhong, Prof. Zhao Xudong, Prof. Zhang Jijiao, etc., who all made distinctive accomplishments in respective research field. ${ }^{1}$ The past several decades also witnessed the tremendous development of Chinese anthropology. Among them, the achievements of prestigious anthropologists such as Prof. Fei Xiaotong, Prof. Qiao Jian and Prof. Li Yiyuan were quite influential and inspiring. The authors attempt to represent their accomplishments as "Qiao Jian's insight,"

\footnotetext{
${ }^{1}$ For the generation division of Chinese anthropologists and ethnologists, the most common standard is roughly every 10 years for one generation. For example, scholars of the first generation are mostly scholars born in the 1880 s to the early twentieth century, such as Cai Yuanpei, Wu Wenzao, etc., while scholars of the sixth generation are mostly born in the 1960s. For the specific division, please refer to: Zhang Jijiao, 2015. Comparative Analysis of Contemporary Anthropological and Sociological Theories: Post-Modernism or Institutionalism. Journal of South-Central University for Nationalities (Humanities and Social Sciences), vol. 35(5), pp. 31-36.
} 
"Fei Xiaotong's thinking" and "Li Yiyuan's attempt," "2 which laid foundation for the future development of Chinese anthropology.

\section{“Qiao Jian's insight"}

“Qiao Jian's insight” develops from Qiao Jian's understanding of the development of anthropology in China. In his article The Predicaments and Prospects of the development of Chinese Anthropology (1995), he pointed out four predicaments and four prospects ahead for Chinese anthropology. One predicament, which triggered an intensive discussion in academic circles, is that the existing anthropological theories and research methods are not sufficient to study contemporary Chinese society altogether (Qiao 1995). The predicament mentioned by Qiao Jian implies that the pre-modern society theories are not completely suitable for studying modern civilized society with complexity, historicity and mobility, if there is only one discipline involved. Therefore, it would be necessary for Chinese anthropology to carry out an interdisciplinary comprehensive research, which was later well verified in the large-scale project of "Loess Civilization Jiexiu Model" presided over by Qiao Jian. This interlude suggests that it's urgent for Chinese anthropologists to further refine and deepen research methods, update research paradigm, transform anthropological knowledge into practice, and make achievements that will contribute to the world anthropological community, even to the whole humanities and social sciences (Zhou et al. 2015). Qiao Jian's individual understanding of anthropology sparked a hot debate on Chinese anthropology, so we call it "Qiao Jian's insight" to hail his achievement.

Throughout Qiao Jian's life history as an anthropologist, he had truly shouldered the responsibility that Chinese anthropologists should have. This responsibility is to draw lessons from Western anthropological theory to explain and verify Chinese society, meanwhile finding the way to "localization" of Chinese anthropology through domestic investigation and practice (Qiao and Xu 2013). For example, Qiao Jian presented a new concept of "bottom society" (Qiao 2002) to study the complexity of civilization and urban civilization, which offered a model for Chinese anthropologists to propose localized theories.

\section{"Fei Xiaotong's thinking"}

Prestigious Chinese anthropologists, have made anthropological interpretations on modern society. Among them, the most prominent anthropologists maybe Prof. Fei Xiaotong, and we call his investigation and researches on Chinese social reality as "Fei Xiaotong's thinking".

\footnotetext{
2 These three are not the successive relations, but the parallel relations. They are all the thoughts and efforts around the development of anthropology in China. This paper puts "Qiaojian' insight" at the front, mainly in response to Qiaojian's The Predicaments and Prospects of the Development of Chinese anthropology.
} 
His Peasant Life in China discusses the rural industrialization in China (Fei 2001). Prof. Fei pointed out that Chinese farmers couldn't deal with the great impact of Western industrialization on China's rural silk industry effectively, and the only way they could do was to take orders from rural industrialization as a passive role, which is his thinking on Chinese social reality. Later, he put forward the "differential mode of association" theory (Fei 1948) to understand the structure of Chinese society, compared with Western society. Prof. Fei Xiaotong's researches also influenced Nakane Chie, a Japanese anthropologist, who put forward the concept of "vertical society" (Nakane Chie 1994) 19 years later to describe the social structure of Japan. Therefore, the concept of "differential mode of association" proposed by Fei Xiaotong is in the same league as his Western counterparts, such as Durkheim's "mechanical solidarity" and "organic solidarity" (Durkheim 1997), Tonnies's "community" and "society" (Tonnies 1957), which help us understand the structure of Chinese society. All above can be seen as the first stage of Fei Xiaotong's practical thinking.

In 1988, Fei Xiaotong put forward the "pluralistic integration" theory of Chinese Nation in his speech at Chinese University of Hong Kong (Fei 1989) to analyze the relationship between nations, nation and state in China, which is the most fundamental relationship in the theory of nation. Besides, the development of Chinese Nation and its practical problems is of academic and practical significance of Chinese ethnology and anthropology, considering ethnic topics as an important aspect of China's state governance. In this sense, it can be seen as the second stage of Fei Xiaotong's practical thinking.

After that, Fei Xiaotong put forward the concept of "cultural consciousness" in 1997, as a viewpoint of the relationship between Chinese culture and Western culture; because since the reform and opening up in 1978, China had made great progress, while a huge gap still existed between China and the West (Fei 1997). Therefore, Fei Xiaotong's thinking about the reality of Chinese society has gone through "differential mode of association" to "pluralistic integration of Chinese nation" and then to "cultural consciousness", which sheds light for our further study.

\section{“Li Yiyuan's attempts"}

In exploring Chinese anthropological localization, Prof. Li Yiyuan made great achievements, and "Li Yiyuan's attempts" has played a key role in anthropology localization in China. Like Fei Xiaotong, Li Yiyuan paid special attention to the localization of social sciences. From the early 1980s to the late 1990s, Hong Kong and Taiwan academic circles had been discussing the issue of localization of social and behavioral science and published relevant proceedings. ${ }^{3}$ Among them, Li Yiyuan stated his view directly: "it is a high-level work to establish theories and methods suitable for the study of Chinese people and Chinese culture, or to revise

\footnotetext{
${ }^{3}$ Qiao Jian, (ed). Symposium on Modernization and Chinese culture [C]. Chinese University of Hong Kong, 1985; Yang Guoshu and Wen Chongyi, (eds). Sinicization of Social and Behavioral Sciences [M]. Institute of Ethnology, Academia Sinica, Taipei, 1991.
} 
Western theories and methods in the process of anthropological localization. The localization of a discipline should not only involve its local and domestic content, but more importantly, it should show the characteristics of its own culture in theories and methods, rather than blindly pursue the Western models (He 1998)."

For years, $\mathrm{Li}$ had been committed to doing interdisciplinary researches and led a comprehensive research project- "Culture, Qi and Traditional Medicine" in "Academia Scinica", Taipei. This project had successfully gathered numerous anthropologists, psychologists, economists, dancers, religionists, traditional Chinese medicine practitioners, basic medical researchers, physicists, etc., trying to make a localized cognitive scientific research on the complex relationship of Qi in Chinese culture (He 1998). In our opinion, the interdisciplinary comprehensive research led by $\mathrm{Li}$ Yiyuan has important value for us to explore the major issues of contemporary Chinese society in anthropological researches. Therefore, we should continue to carry out practical researches, like interdisciplinary comprehensive researches and crosscultural comparative researches, to argue new ideas on Chinese society in the transformation period, which promises a bright future for Chinese anthropology.

\section{Results}

\section{Developments: missions of Chinese anthropology}

At present, with the continuous development of reform and opening up, China's economic and social structure has been undergoing a huge transformation from an agricultural society to an industrial society, and from a planned economy to a socialist market economy. ${ }^{4}$ In the face of this great change, Chinese anthropologists realize that current anthropological theories and research methods could not effectively explain Chinese society at a transitional period. Then, how should Chinese anthropology achieve self-development, or explore the new direction of anthropology with Chinese characteristics to build the discipline system of Chinese anthropology in the new era, as well as to make it a prominent discipline in contemporary Chinese society, have become the missions of contemporary Chinese anthropologists.

Since the 16th World Congress of the International Union of Anthropology and Ethnology (IUAES) was successfully held in Kunming in July 2009, Chinese anthropologists have done a lot to avoid anthropology being marginalized again, such as

\footnotetext{
${ }^{4}$ Zhang Jijiao(ed), 2015. A New Round of Urbanization, Industrialization, Marketization, and Cultural Diversity: A Discussion on Globalization and Modernization. Beijing: Intellectual Property Publishing House; Zhang Jijiao 2015. The Perspective of Enterprise Anthropology: How to Look at a New Round of Industrialization, Marketization, and Urbanization. Innovation, Vol. 56, No.2, pp.27-36; Zhang Jijiao \& Liu Shigang, 2016. Reflections on the Current Transformation of China's Economic and Social Structure. Journal of Guangxi Teachers Education University (Philosophy and Social Sciences), Vol.35(1), pp.1-5; Zhang Jijiao \& Song Dan, 2017. On the Modern Transformation of Chinese Anthropology and Ethnology: Facing to Industrialization, Marketization and Urbanization. Journal of Guangxi Teachers Education University (Philosophy and Social Sciences), Vol.38, No.4, pp. 37-44; Zhang Jijiao \& Yang Lin, 2017., On the Five Rounds of Transformation in China's Economic Structure Since the 1860s. Journal of Guangxi Teachers Education University (Philosophy and Social Sciences), Vol. 38, No.5, pp.87-94.
} 
exploring the new direction of Chinese anthropology, strengthening the construction of the discipline system of Chinese anthropology in the new era, trying to walk out of the dilemma of traditional rural and community researches, and bringing anthropological researches into the grand narrative context of the current economic and social transformation of China. Chinese anthropologists and ethnologists are making joint efforts to explore "the road of Chinese schools."

After more than ten years' efforts, Chinese anthropologists have made great progress both in theories and practice, which is embodied in two aspects: one is interdisciplinary comprehensive researches and cross-cultural comparative researches based on the thinking and efforts of prestigious anthropologists such as Qiao Jian, Fei Xiaotong, and Li Yiyuan; second is the new direction and construction of discipline system of Chinese anthropology in the new era pursued by contemporary Chinese anthropologists.

Recently, according to the list of members of the China Union of Anthropological and Ethnological Sciences (CUAES), we have retrieved the number of published anthropological papers in China National Knowledge Infrastructure (CNKI) of these members as well as some famous scholars in the last three years, hoping to give an overview of the development of anthropology in China. According to our calculation, candidates must publish 5 papers or articles (including articles of some important newspapers) every year in the last 3 years (Table 1). Relevant statistics are as follows:

As shown in the above table, the top 26 mainland anthropologists are all wellknown professors in China. They are generally the discipline leaders of anthropological departments or faculties. Some of them were also given the title of Yangtze River scholars, an official recognition of distinguished professors. It can be said that they are the main force to construct the discipline system of contemporary anthropology with Chinese characteristics. It can be seen from the above table that some scholars are very active, with more than 15 papers published annually. Some of them have made meaningful explorations in their respective research fields, such as Prof. He Xingliang's study on the "Belt and Road Initiative" and a community with a shared future for mankind, Prof. Wang Yanzhong, Prof. Ma Guoqing and other scholars' study on building the community for Chinese Nation, Prof. Peng Zhaorong's study on rural revitalization, Prof. Zhao Xudong's study on cultural transformation, Prof. Zhou Daming's study on urban immigration society, Prof. Zhang Jijiao's study on enterprise anthropology and so on, which all lead the new directions of contemporary development of Chinese anthropology.

In order to explore the new directions of Chinese anthropology in the new era, Chinese anthropologists have been committed to carrying out interdisciplinary

\footnotetext{
5 The theme of the 2019 annual meeting of the Chinese Association of Ethnology is "Seventy Years of New China's Ethnology and the Road of Chinese Schools of Ethnology". It was held in Beijing from October 12th to 13rd, 2019. The organizers are the College of Ethnology and Sociology of Minzu University of China and the Institute of Ethnology and Anthropology of the Chinese Academy of Social Sciences. Nearly 200 representatives from all over the country attended the meeting.
} 
Table 1 The list of the number of published anthropological papers by top 26 anthropologists in recent 3 years (unit: article)

\begin{tabular}{llllllll}
\hline Name & 2016 & 2017 & 2018 & Name & 2016 & 2017 & 2018 \\
\hline Peng Zhaorong & 23 & 23 & 36 & Yang Tingshuo & 14 & 8 & 3 \\
Zhao Xudong & 19 & 29 & 24 & He Xingliang & 8 & 8 & 7 \\
Zhang Jijiao & 19 & 22 & 17 & Du Jing & 6 & 9 & 7 \\
Jin Binghao & 21 & 27 & 7 & Xu Jiexun & 7 & 7 & 7 \\
Zhou Daming & 15 & 16 & 14 & Fan Ke & 6 & 7 & 8 \\
Fang Lili & 12 & 15 & 8 & Ma Guoqing & 6 & 8 & 6 \\
Naran Bilik & 12 & 14 & 8 & Zhang Xiaojun & 7 & 4 & 7 \\
Chen·Bateer & 8 & 9 & 13 & Wang Mingming & 7 & 5 & 5 \\
Ma Rong & 14 & 5 & 10 & Gao Yongjiu & 4 & 6 & 7 \\
Xu Lili & 11 & 10 & 7 & Gao Bingzhong & 7 & 7 & 1 \\
Wu Dahua & 11 & 9 & 8 & Jing Jun & 6 & 6 & 3 \\
Wang Yanzhong & 6 & 6 & 14 & Li Jing & 3 & 5 & 7 \\
Chen Zhiping & 9 & 9 & 8 & Zhao Shiyu & 6 & 2 & 5 \\
\hline
\end{tabular}

comprehensive researches and cross-cultural comparative researches in depth and striving to build the discipline system of Chinese anthropology.

\section{Interdisciplinary comprehensive researches}

Getting to know the essential characteristics of anthropology is the first step if we want to explore the new directions of Chinese anthropology and construct the discipline system of anthropology. When it comes to the essential characteristics of anthropology, ethnography would pop up among the mind of certain scholars. Unfortunately, instead of ethnography, the essence of anthropology lies in interdisciplinary comprehensive researches and cross-cultural comparative researches. After all, anthropology as a subject itself requires multi-cultural comparative or analogical researches in multiple areas and multi-ethnic groups. The Human Relations Area Files (HRAF) established by Murdoch, a famous American anthropologist, has performed the essential characteristics, that is to do cross-cultural comparative researches in multiple regions and countries, as well as comprehensive researches within disciplines, which could be deemed as a benchmark for our own anthropology study.

For Chinese anthropologists who want to carry out interdisciplinary comprehensive researches or cross-cultural comparative researches, they need to be equipped with multi-disciplinary knowledge on the one hand, and strengthen their ability on interdisciplinary teamwork on the other hand.

The core of interdisciplinary and cross-cultural researches lies in "cross", which is to cross the barriers between disciplines and cultures. For example, when we investigate an enterprise or analyze the economic development of an area, we must have relevant knowledge of enterprise management or economics. That is to say, 
when we carry out the researches of a certain sub-discipline (such as medicine, art, education, enterprise management, etc.), we must be equipped with considerable knowledge of these disciplines, instead of only taking anthropology as a supplementary tool for data collecting.

Here, we take Prof. Zhang Jijiao, the founder of enterprise anthropology, a subdiscipline of anthropology as an example. Prof. Zhang studied anthropology at Sun Yat-sen University during undergraduate study, and then worked at the Institute of Ethnology and Anthropology Sociology of Chinese Academy of Social Sciences. A few years later, he studied sociology with Prof. Li Peilin, a famous Chinese sociologist, for Ph.D. His research direction was industrial sociology at that time. In 1997, Zhang Jijiao began to do some researches on market and business management. From 2001 to 2004, he published 6 monographs and translated works on business management. ${ }^{6}$ Later, Prof. Zhang turned to study urban migration from which he acquired certain knowledge on emigration and immigration, including various theories and methods at home and abroad. ${ }^{7}$ When he turned to study the ecological environment, Zhang Jijiao learned a lot about environmental science from his wife, a scholar in environmental studies. Based on Zhang's rich interdisciplinary background, we could find out that researchers should not only have professional knowledge in a certain field, but also need comprehensive knowledge of related disciplines. Only in this way can we do a good job in cross-cultural comparative researches, as well in interdisciplinary researches.

Although Zhang Jijiao's academic researches involve many fields (urban migration, informal system, value chain management, time-honored enterprises, ecological environment, etc.), all these researches finally concentrated on two branches of anthropology (urban anthropology, and enterprise anthropology). In fact, Zhang Jijiao's researches aimed at grand modern narratives, namely, how to explain the transformation of China's economic and social structure over the past 40 years.

\footnotetext{
${ }^{6}$ Zhang Jijiao, Value Chain Management: Optimizing Business Process and Improving Comprehensive Competitiveness of Enterprises, Beijing: China Price Press, 2001; Zhang Jijiao \& LV Jianghui (eds), Digital Management: Meeting Challenges and Controlling the Future, Beijing: China Price Press, 2001; Zhang Jijiao, Ge cunshan \& Shuai Jianhuai, Distribution Chain Management: Design, Control and Management Innovation of Distribution Channels, Beijing: China Price Press, 2002; Zhang Jijiao \& Shuai Jianhuai (eds), Successful Brands Management, Beijing China Price Press, 2002; Zhang Jijiao, Control Chain Management: Preventing Customer Risk and Receivables Risk, Beijing: China Price Press, 2003; Gaeme Drummond \& John Ensor, Strategic Marketing: Planning and Control, translated by Zhang Jijiao \& Tian Yongpo, Beijing: China Market Press, 2004.

7 Zhang Jijiao, Adaptation to Cities: Employment and Entrepreneurship of Migrants, Beijing: The Commercial Press, 2004; Zhang Jijiao, Urban Migrants in Asia: A Comparison of China, South Korea, and Malaysia, Beijing: Intellectual Property Publishing House, 2009; Zhang Jijiao \& Zhang Yunhua, Urban Migrants in Asia: An Interview with 50 Chinese Leaders, Chinese Businessmen and Managers in Southeast Asia, Beijing: Intellectual Property Publishing House, 2009; Zhang Ji Jiao \& Shen Lin: Urban Migrants in Asia: A Survey of Four Chinese Cities: Shenzhen, Qingdao, Hohhot, Kunming, Beijing: Intellectual Property Publishing House, 2009;Ellen R. Judd and Zhang Jijiao (eds), Labor Migration and Social Mobility in Asia and Pacific Region, Beijing: Intellectual Property Publishing House, 2011. Zhang Jijiao \& Howard Duncan (eds), Migration in China and Asia: Experience and Policy, International Perspective on Migration 10, Netherlands: Springer Science + Business Media B. V., 2014.
} 
Generally speaking, it is difficult for one person to complete the whole interdisciplinary comprehensive researches and cross-cultural comparative researches. Teamwork is the key. In today's anthropological research paradigm transformation from community research to regional research, a jointly regional research is not an alternative, but is a necessity for Chinese anthropological researches. One typical example is "Southern China School" of Chinese historical anthropology. Since the 1980s, historians such as Chen Chunsheng, Liu Zhiwei and Zheng Zhenman have been cooperating with anthropologists such as Helen Siu and David Faure on traditional Chinese society from the perspective of historical anthropology in southern China, combining with methods of anthropological observation and historical interpretation of local documents and archives. They have made remarkable achievements and formed the "Southern China School" of Chinese historical anthropology (Zhou 2006). Another example is the study on ethnic corridors. Wang Mingming regarded the regional study on the Tibetan-Yi Corridor proposed by Fei Xiaotong as an example of comprehensive study, which needs to combine researchers from different disciplines, working as an exchange platform to strengthen cooperation with relevant foreign universities and scientific research institutions (Wang 2007).

In 2013, Qiao Jian, Zhou Daming and other scholars from Sun Yat-sen University, Sichuan University, Fudan University, and Xiamen University jointly launched the large-scale project of "Loess Civilization - Jiexiu Model" under the entrustment of Jiexiu municipal government, and conducted in-depth researches on the local culture of Jiexiu from the aspects of history, ethnicity, geography, cultural heritage, etc. At the same time, the research group also invited foreign scholars, hoping to form an interdisciplinary vision and enhance communications between China and the Western academic circles. Its purpose is to achieve a holistic understanding of Jiexiu, a region nurtured by the Loess civilization, by means of interdisciplinary cooperation (Zhou et al. 2015).

In addition to regional researches, interdisciplinary cooperation also covers some specific issues of modern society. For example, "the protection and utilization of cultural heritage" is a systematic work that needs multi-disciplinary knowledge to carry out protection and planning research. Prof. Peng Zhaorong vigorously advocated that all disciplines work together to establish an intangible cultural heritage system with Chinese characteristics, build a "Chinese Paradigm" of intangible cultural heritage research to get out of the dilemma of "heritage without system" in China (Peng 2012).

However, interdisciplinary comprehensive research only solves the survival problem facing Chinese anthropology during the transitional period. It's still a long way to go for Chinese anthropology as an independent subject during the current economic and social structure transformation. Therefore, if Chinese anthropologists wanted to explore a new direction, the discipline system is certainly on the mark.

\section{The discipline system of Chinese anthropology}

Recent years have witnessed the construction of discipline system of Chinese anthropology in the new era pursued by contemporary Chinese anthropologists. 
Over the past decades, significant achievements have been made in Chinese anthropology, especially in three aspects. The first is localization of anthropology with less dependency on the Western theories and more self-dependence. The second is modernization of anthropology which demands more adaptability and less discipline inertia. The third is internationalization of anthropology to reduce discipline closeness by strengthening international communication and cooperation.

The term of "anthropological localization" has drawn much attention from scholars at home and abroad. In our view, it means to seek for the unique anthropological understanding of Chinese culture and Chinese society on the premise of Chinese cultural consciousness, and also gradually get rid of the shackles of Western theories and research methods, so as to form a unique theoretical system and knowledge structure of Chinese anthropology. To realize the localization of anthropology and improve disciplinary independence, Chinese anthropologists should start from two aspects: the one is to build a theoretical framework of local knowledge system, and put forward some localized concepts and construct theories with Chinese characteristics; the other is to establish Chinese schools of anthropology, such as the rural school of Chinese anthropology and the urban school of Chinese anthropology.

First of all, it is urgent for Chinese anthropologists to build a theoretical framework of local knowledge system, including localized concepts and theories, through the unique understanding of Chinese culture and society. In this respect, Fei Xiaotong had contributed a series of local concepts and theories based on Chinese social reality, including the concept of "differential mode of association" (Fei 1948), the notion of "cultural consciousness" (Fei 1997) and the theory of "Tibetan-Yi Corridor", and many following scholars have enriched and extended his thinking in according with actual development and situations. For example, Zhang Jijiao has developed his "differential mode of association" (Zhang 2004) to an urban version to analyze the complex structure of modern Chinese cities, and promoted his "cultural consciousness"(Zhang 2017) to a higher level as "cultural confidence" based on China's political and economic rise in decades, while Li Shaoming has developed Fei's ethnic corridors theory ( $\mathrm{Li} 2007)$.

In addition, Chinese anthropologists have revised some Western theories based on Chinese social reality. For example, He Xingliang once questioned Morgan's view which proposed the oldest human kinship system with five grades, while Prof. He held that the oldest kinship system should be divided into three grades: the old, the middle and the young, which was based on the kinship system of Kazak, Kirgiz and Han ethnic groups (He 1982). Chen Qinan, Wang Mingming and other domestic scholars questioned Freedman's research paradigm of Chinese lineages; He Guoqiang criticized the one-sided discussion in Karl A. Wittfogel's Oriental Despotism: A Comparative Study of Total Power.

In terms of anthropological localized theories, "Pluralistic Integration of Chinese Nation", proposed by Fei Xiaotong, becomes the guiding theory to understand and solve the ethnic issues in China. Inspired by this, Xu Jieshun put forward the "snowball" theory, which is based on a series of researches on Han people (Xu 1999). Li Yiyuan's theory of "three levels of equilibrium and harmony" is also a typical representative of anthropological localized theories (Li 2013). At the end of 1990s, Yang Tingshuo put forward interphase (Xiangji) operational theory with Chinese 
characteristics, through the long-term ethnographic studies on the Chinese southwest minorities and the reflections on the theoretical viewpoints of Western traditional economics, which is regarded as the localization model of economic anthropology (Yang 1995). In 2014, the publication of The Theories of Symbolic Anthropology by Qu Mingan can be regarded as an important achievement of the localized theory of anthropology in recent years. From the perspective of localization, he combines the theories and research methods of Western symbolic anthropology with the reality of China to start up the theoretical construction of Chinese symbolic anthropology. In this book, as an attempt to analyze the Chinese Confucian culture in symbolic anthropology, he points out that the "rite" in Confucian culture is "a set of symbolic system with Chinese characteristics" (Qu 2014).

Secondly, compared with Western anthropology, there was an obvious drawback in Chinese anthropology, which is the long-term absence of local schools. Although there are many well-known anthropologists in China, Chinese anthropology did not have an overall planning to coordinate all their studies as a whole, so that most Chinese anthropologists just carried out independent researches in their own fields, which led to Chinese anthropological theories developed in a spontaneous way for a long time, falling into a decentralized and unsystematic situation. To reverse this unfavorable situation of "working on their own" and narrow the gap between Chinese and Western anthropology, Chinese anthropologists began to establish local schools, coordinate studies of various fields, and build a local knowledge system, to bring Chinese anthropological achievements into international academia, and gradually improve the academic status of Chinese anthropology. According to the current academic progress and relevant achievements of Chinese anthropology, in terms of research scope and research object, two schools of Chinese anthropology have gradually come into being, i.e., the rural school of Chinese anthropology, represented by Wu Wenzao, Fei Xiaotong, Lin Yaohua, Yang Qingkun, Li Anzhai, Tian Rukang and other scholars since the 1930s (Xu and Liu 2012); the urban school of Chinese anthropology, represented by Ruan Xingyun, Zhou Daming, Zhang Jijiao and other scholars since the 1990 s.

"The rural school of Chinese anthropology" was put forward by Xu Jieshun in the article The Chinese Rural School of Anthropological Studies-In Connection with the Centennial of Mr. Fei Xiaotong and Mr. Lin Yaohua (Xu 2010), and was unanimously appreciated by most scholars in the domestic anthropological circle. In 2012, in his book Rural Anthropology (co-authored with Liu Bingqing), Xu Jieshun once again demonstrated the formation and development of "rural school of Chinese anthropology" in detail by combing, refining and summarizing the rural studies of Chinese anthropology in the past 100 years (Xu and Liu 2012).

Since the functionalism and community research was introduced into China in the 1930s, Chinese sociologists and anthropologists who shouldered the responsibility of understanding China and transforming China had taken this opportunity to study rural society in China. Fei Xiaotong's Peasant Life in China (1939), Earthbound China: A Study of the Rural Economy of Yunnan (co-authored with Zhang Zhiyi) (1943), From the Soil: The Foundations of Chinese Society (1948), Lin Yaohua's Patriarchal Clan Study in Yixu (1935) and The Golden Wing: A Sociologist Study of Chinese Family (1948), and Martin C. Yang's A Chinese Village: Taitou, 
Shantung Province (1945), Francis L. K. Hus's Under the Ancestors' Shadow: Kinship, Personality \& Social Mobility in China (1968), and so on, are all regarded as the starting points of the formation of the rural school of Chinese anthropology. These scholars chose to study Chinese society and culture in rural areas, and pioneered the study of complex civilized society. Therefore, the study of rural society in China is not only a feature of Chinese anthropology, but also a great contribution to the international anthropology.

For more than 80 years of development, the focus of Chinese anthropology has always been on rural studies, and several academic echelons have come into being. The academic teams also have been growing, ranging from Fei Xiaotong, Lin Yaohua and other founders of local rural study in the 1930s and 1940s, to Wang Songxing, Zhuang Yingzhang, Li Yiyuan, etc. in the 1950s and 1970s, then to Huang Zongzhi, Yan Yunxiang, Huang Shuming, Wang Mingming, Jing Jun, Zhuang Kongshao, Zhou Daming, Cai Hua, Gao Bingzhong. etc. in the 1980s and early twenty-first century. The formation of the academic echelon of Chinese anthropological rural study well inherits the research traditions of Chinese anthropology, which makes rural study the main theme of Chinese anthropology. In this academic echelon, there are not only academic masters, but also distinctive theories, research methods and research paradigms. Since Xu Jieshun set up the banner of "the rural school of Chinese anthropology", Chinese anthropologists who are engaged in rural study should unite under this banner to form a joint force to strengthen the rural school of Chinese anthropology. The fast-growing "Southern China School" of historical anthropology which synthesizes the theories of Chinese social and economic history and the Western Annales School, is a good example to showcase Chinese anthropological achievements.

The starting point of Chinese urban school of anthropology is the introduction of urban anthropology. As Prof. Zhang Jijiao said, "simply speaking, it's the change of Chinese anthropology object from the rural areas to urban areas that brought out urban anthropology (Li 2017)." Compared with the rural school of Chinese anthropology, the urban school is very young, but it walks in front of the rural school of Chinese anthropology, and steps into the forefront of international anthropology. It can be said that to a certain degree, the urban studies at present might reveal some striking features, which can be explained from the following three aspects:

First of all, urban anthropology rose in the Western academic circles in the 1970s, and was introduced into China by Chinese anthropologists in 1989. The merely 10-year gap means Chinese urban anthropology almost started from the same line as their counterparts in the West. As the guide of urban anthropology in China, Ruan Xihu once said: "Compared with China, there are not many new things in international urban anthropology. For the Western anthropology, it is also a new branch discipline, and we are on the same starting line with them (Zhang et al. 2018)."

Secondly, different from the Western urban anthropology, Chinese urban anthropology has shouldered the responsibility of providing theoretical basis for urban ethnic work since its establishment. Therefore, China's urban anthropology innovated the study of ethnic relations, that is, the study of the relationship between urban development and urban ethnic groups, of the social problems related to ethnic groups in the process of urbanization and the role of cities in promoting the 
economic and cultural development of ethnic areas, which is an important contribution of Chinese urban anthropology to provide new research directions and ideas for international anthropology. As Ruan Xihu said, "Chinese urban anthropology was born as an innovator among international anthropology (Zhang et al. 2018)." Later, Chinese urban anthropology also brought Han ethnic group into its study, which expanded the research scope of ethnology and anthropology.

Thirdly, in terms of theoretical achievements, the urban school of Chinese anthropology has formed a relatively complete theoretical system. After more than 30 years' development, the urban school of Chinese anthropology has formed three major research forces: urban anthropology, industrial and commercial anthropology, and enterprise anthropology. Its research scope has expanded from the initial research on the floating population of urban ethnic minorities to the urbanization of ethnic areas, rural urbanization, urban groups and problems, contemporary business organizations, historical commercial districts, cultural heritage and urban revival and so on. During the process of development, the urban school of Chinese anthropology has gradually formed its own theoretical system, that is, "two perspectives, one paradigm, three concepts and one methodology", and completed a "partial breakthrough". "Two perspectives" refer to the observation and analysis of urbanization in ethnic areas or the development of social modernization in China as a whole from the perspective of "transformation of economic and social structure" and the perspective of "urbanization, industrialization and marketization (Zhang 2015);" "one paradigm" mainly refers to the research paradigm of "social structural transformation," that is, social structural elements play an equally important role in resource allocation and economic development as the government and market do, and this theory may also be applicable to other developing countries (Zhang 2016). "Three concepts" refer to the concept of "dual community," used to explain why urban immigrants and urban dwellers belong to two different systems (Zhou 2000); the concept of "beehive society," used to explain the adaptability mechanism of ethnic minorities in the city (Zhang 2018); "umbrella society," used to understand the relationship between enterprise development and the government in the city (Zhang 2016). "One methodology" refers to "four-level analysis approach." Specifically, the first level is the macro-level of "big society" (government, market, society); the second level is the median level of "small society" (market and society); the third level is also the median level (market), and the fourth level is the micro-level of case study (Zhang 2016). "Partial breakthrough" means that the urban school of Chinese anthropology broke through the research paradigm of traditional rural studies, carried out researches on urbanization of ethnic areas and urban ethnic minorities under the guidance of new theories and methods, so as to promote the modernization of anthropology.

To sum up, the local theoretical system of the urban school of Chinese anthropology implies that Chinese scholars have begun to participate in international dialogue equally. The most typical example is that urban anthropology of China successfully held the mid-term conference of the International Union of Anthropological and Ethnological Sciences (IUAES) in Beijing in July 2000. This is the most important and grand international conference organized by the urban school of Chinese anthropology. Sunderland, the former president of the IUAES, spoke highly of the 
conference, "I have worked in the IUAES for more than 20 years and served as secretary general, president and other positions. This is the best mid-term conference I have ever attended (Timur and Shen 2000)."

\section{Adaptability of Chinese anthropology}

Many scholars at home and abroad have emphasized that the twenty-first century is the century of anthropology, which will bring opportunities for Chinese anthropology. In fact, if anthropology makes its own achievements in the new era, it will need to solve practical issues (Geller 2012). Qiao Jian once pointed out that one of the difficulties in Chinese anthropology was the existing anthropological theories and research methods which could not explain modern Chinese society effectively (Qiao 1995). Specifically speaking, the theories of several classic anthropological schools, such as functionalism, structural functionalism, structuralism, interpretivism, symbolism, etc., were only put forward after studying a specific area or a specific theme. None of them can fully explain and analyze the modern complex society, especially the Chinese social economic transformation. Therefore, if Chinese anthropology puts forward insightful views on social problems, it will need to walk out of the traditional rural research paradigm, and turn to study the modern society, especially those practical problems emerged in the transformation of Chinese economic and social structure.

The forty years of reform and opening up saw a huge economic and social structure transformation in China. In the process, China's social development has shown unprecedented vitality, but at the same time, it has brought out many new issues. Contemporary social issues have presented a diversified trend, such as urban floating population, food safety, transformation of economic and social structure, industrial transformation, cultural heritage protection, medical and health care, urbanization of ethnic areas, ecological protection of ethnic areas, ethnic corridors, The Belt and Road Initiative, the community for Chinese Nation, which are to be studied urgently by Chinese anthropology.

At present, some Chinese anthropologists have begun to pay attention to the realistic issues of modern society. For example, when Prof. Zhou Daming started the researches on rural urbanization, he also paid attention to the problems related to modern society. With the fast-growing urbanization after the reform and opening up, the urban floating population is increasing, and the urban migration issues have thus become his main research object. In the subsequent researches, he put forward some new concepts, such as dual community, pendulum theory and so on, which provide a better understanding of Chinese reality. Prof. Zhao Xudong seized the historic opportunity of cultural transformation brought by social transformation, and steered Chinese anthropology towards cultural transformation. From 2014 to 2018, more than 10 papers on cultural transformation have been published, contributing to the further development of anthropology in China (Xu et al. 2018). In recent years, Prof. Jing Jun has made great achievements in the study of AIDS and other public health issues. He applies some sociological and anthropological ideas to the construction of China's AIDS epidemic and 
prevention indicators, and discusses China's AIDS risk through the elaboration on the "Titanic law (Zhuang et al. 2009)."

In addition to the study of practical events, Chinese anthropology also has an eye on national policies, such as the Belt and Road Initiative, the community for Chinese Nation and the community with a shared future for mankind, and so on. Therefore, Chinese anthropology has already actively participated in the national construction, which will definitely make itself a prominent discipline in the new era.

Since Liang Qichao formally proposed the concept of Chinese Nation more than 100 years ago, it has always been an important theme of Chinese anthropology and ethnology. So far, Chinese anthropologists have made many achievements, among which the most representative one was Fei Xiaotong's theory of "pluralistic integration of the Chinese Nation." The theory systematically discusses the natural formation of the Chinese Nation historically during multi-ethnic and multi-level integration. Today, CPC (Communist Party of China) Central Committee, represented by President Xi Jinping, puts forward the guideline of national work in the new era that is to create a strong recognition of our national identity. So, in the new era, how should we cultivate this identity?

Prof. Wang Yanzhong holds that the theoretical consciousness is an essential precondition for the construction of the community for the Chinese Nation, and then we should build the discipline system, academic system and discourse system of ethnic theories in the new era. In other words, he points out the direction of Chinese anthropology from the theoretical level (Wang 2018). In comparison, Prof. Ma Guoqing gives some suggestions from the practical level. He believes that the community for the Chinese Nation is a multi-level system. Therefore, in order to understand this concept deeply, we must divide this community into different levels of social structure, and make the system of the community for the Chinese Nation comply with Chinese reality in the process of the interaction between the nation and society (Ma 2017).

Meanwhile, to embrace globalization, the Chinese government put forward the Belt and Road Initiative on the prospect of building the community with a shared future for mankind, which provides historical opportunities for the development of Chinese anthropology. The implementation of the "Belt and Road Initiative" requires Chinese anthropology to go overseas and actively carry out overseas ethnographic researches in countries and regions along the "Belt and Road." Through a series of overseas ethnographic studies, we can announce to the world that China's "Belt and Road Initiative" is not a "geo-strategic" tool accused by several foreign scholars and politicians who claim this policy as a disaster to the existing international order, or "dumping excess capacity." Instead, it is a contribution to the common development of mankind (He 2018). Wu Xiaohua believes that the proposal of the "Belt and Road Initiative" not only creates unprecedented opportunities for the rejuvenation of the Chinese Nation, but also brings new opportunities for the common development of the people around the world today. It links China with the rest of the world. Specifically, according to Wu Xiaohua, the "Belt and Road Initiative" can be promoted in six aspects, that is, economic corridor construction, infrastructure construction, cultural identity construction, regional security construction, mutual responsibility construction, and green sustainable construction (Wu et al. 2018). 
Moreover, some Chinese anthropologists prefer to discuss the realistic issues from the historical perspective. The importance of ethnic corridors, particularly the relationship between the ethnic corridors and the "Belt and Road Initiative" is on the rise. Prof. Zhou Daming thinks that the formation of ethnic corridors in history is a centripetal process, which began to gather Chinese people into one nation. Based on the "Belt and Road Initiative," the studies on ethnic corridors will provide a larger regional perspective in understanding China. The combination of the two can form a corridor research paradigm (Zhou et al. 2018). Xu Lili attempts to find the vitality of the "Belt and Road Initiative" from historical traditions of the ancient "Silk Road," and explores the new ideas of Chinese frontier governance with ethnic corridors (Xu 2017). Zhao Xudong believes that the "Belt and Road Initiative", brought out as a national strategy, brings the concept and scope of corridor to the international academic community, which will help form the concept of the world's ethno-national corridor, and provides a historical opportunity for overseas ethnographic studies of Chinese anthropology (Zhao et al. 2017).

Under the background of social transformation in China, many scholars have begun to focus on the changes and adaptation of the traditional research objects of anthropology in the modern society. Given that the past bisection ("opposition-assimilation") method is not suitable for the study on the modern world, therefore, we propose a four-form method, that is, the forms of opposition, conformity, coexistence, and connection to analyze the relationship between tradition and modernity. Among the four forms, coexistence and connection, called as the "parallel" mode, are the key forms, which can be understood from the following two levels:

Firstly, on the cultural level, the "parallel" mode helps us understand the changes and adaptation of traditional culture in the modern global context. With the deepening globalization, global homogeneity is not the only result, and localization maybe another outcome. So we can see local traditional culture in a set of self-expression discourse system, thus forming a structure of coexistence and connection of local tradition and global modernization. At present, the most discussed issue about the change and adaptation of traditional culture in the modern context is the protection of cultural heritage. On this issue, Chinese anthropology is undoubtedly ahead of other disciplines. The anthropologists have discussed the protection of cultural heritage on the basis of their own fieldworks. For example, Fang Lili uses anthropological methods to discuss the protection of cultural heritage from the social group life of folk kiln craftsmen in Jingdezhen, trying to find useful ways to protect and inherit the traditional culture, especially the traditional handicrafts when they are facing the modern transformation (Fang 2000). In terms of how to protect and inherit traditional crafts, Wan Fubin's Traditional Crafts from the Perspective of Anthropology is a representative work. Combining the theories and methods of scientific anthropology and cultural anthropology, this work takes the traditional crafts of ethnic minorities, such as paper-making of Zhuang people, brocades of Zhuang people, batiks of Miao people, costumes of Dong people, etc. as the research objects, and discusses the necessity and importance of studying 
the traditional crafts of ethnic minorities in the context of modernization (Wan et al. 2011). However, all related studies from the local perspective are incapable of promoting the whole national cultural heritage protection. In this regard, Peng Zhaorong, in combination with the current national strategy of "Rural Revitalization," explores the protection and development of cultural heritage in the local society from the perspective of tourism anthropology. He promotes to establish an intangible cultural heritage system with Chinese characteristics, construct a "Chinese paradigm" of intangible cultural heritage research, and change the current situation of "heritage without system" in China (Peng 2012). In addition, among those traditional issues in modern transformation, the revival and transformation of Chinese lineage in modern society has also drawn scholars' attentions. For example, Qian Hang's “transformed Chinese lineage," Du Jing's "fountain society" and Zhou Jianxin's "cultural struggle" are all valuable explorations and reflections on the Chinese lineage in modern society.

Secondly, on the social level, the "parallel" mode can help us better understand the transformation of traditional social structure in the modern society. In recent years, we have been thinking about how to use multi-disciplinary theories and methods to solve the puzzle of economic and social structure transformation. Before that, Fei Xiaotong had made some explorations. At the beginning of 1986, after investigating the township enterprises in southern Jiangsu (Sunan) and household industries in Wenzhou, Zhejiang province, Fei Xiaotong pointed out that the "Sunan model" was a kind of collective enterprise management model, which mainly derived from the commune system, and the "Wenzhou model" mainly referred to Wenzhou's household industries and professional market, which represented the individual economy as "small commodity, big market (Fei 1983)." During the 15 years from 1988 to 2003, Fei Xiaotong went to Guangdong several times to make some follow-up studies. He used the "Pearl River model" to summarize several development paths in the Pearl River Delta and its radiation areas, such as Shunde model, Nanhai model, Zhongshan model and Dongguan model (Fei 1992). After that, Fei Xiaotong put forward the concept of "regional development" in order to interpret the development of China's economy and society from the macro level. Throughout Fei Xiaotong's academic trajectory, he had come a long way from the initial rural community research to the later proposed concepts of various "models" and "regional development," in which every concept and research method serve as an explanation for the development of China's social reality.

In the context of China's economic and social transformation, a group of scholars led by Prof. Zhang Jijiao, strive to promote Chinese anthropology to be a more independent modern discipline by freeing itself from traditional constrains. They advocate a "four-level analysis approach" (Zhang 2017) to study the time-honored brand enterprises, the historical commercial streets, urban revival and urban competitiveness, as well as the transformation of economic and social structure. (Zhang 2017). In addition, in the past two years, the two concepts of "umbrella society" and "beehive society" gave an impetus to the advance of China's transformational structural study. 


\section{Discussion}

\section{Prospects: internationalization of Chinese anthropology}

Since the 1990s, the internationalization of Chinese anthropology, as a trend coexisting with the localization of Chinese anthropology, has enjoyed widespread popularity among scholars. For example, according to Naran Bilik, "the development of modern society requires Chinese anthropologists to strengthen multi-disciplinary communications and researches, especially to understand and make use of the experience and achievements of overseas interdisciplinary comprehensive researches (Naran 1996)." He Xingliang believes that localization and internationalization are a pair of structures supplementing each other. The relationship between the two is related to the overall development of Chinese anthropology in the twenty-first century (He 2000). At present, there are two main directions for the internationalization of Chinese anthropology: one is to carry out overseas ethnographic researches; the other is to actively participate in international academic activities and strengthen cooperation within the international academic community.

\section{Overseas ethnographic researches}

Although Chinese anthropology has been engaged in the study of Chinese local society since its introduction, mainly about the study of ethnic minorities and the study of the Han, there are also many prestigious anthropologists in the study of foreign cultures, such as Wu Zelin's study on American ethnic issues in the 1920s, Li Anzhai's ethnological investigation of the Zuni people in New Mexico, Tian Rukang's study on the social structure of the Chinese in Sarawak, Li Yiyuan's research on the life of the Chinese in Mapo Town, Malaysia, Fei Xiaotong's research on the Americans, Francis L. k. Hsu's comparative research on the world outlook and nationality of the Chinese, Indians and Americans, Wu Yanhe's research on the centennial history of the Chinese in Papua New Guinea, Qiao Jian's research on the Indians in North America, such as Navajo, Zuni, Maya, etc. These scholars pioneered overseas ethnographic researches, and accumulated valuable experience for their following Chinese anthropologists. After years' development, overseas studies on different cultures remain a treasure for Chinese anthropologists. In recent years, with the continuous rising of China's economy and the joint efforts of all sectors of society, more and more Chinese scholars go abroad to carry out overseas researches.

With the increasingly closer connection between China and the world, the Chinese government has also begun to encourage universities to perform overseas researches to meet the needs of the national development. Especially in 2011, the Ministry of Education issued a document on the "Going Global" Plan for Philosophy and Social Sciences in Higher Education, which has set off a wave of overseas researches in universities all over the country. In this wave, anthropology, the protagonist of cultural study, should take the initiative. Therefore, in order to better carry out overseas researches and expand the research fields of Chinese ethnology and anthropology, in November 2011, the Institute of Global Ethnology 
and Anthropology was officially established in the Minzu University of China. This is a milestone to show that Chinese anthropology has formally incorporated overseas ethnographic researches and talents into a united force in teaching and researches. In addition, in response to the Belt and Road Initiative, the Institute of Area Studies was formally established in Peking University in April 2018. In September of the same year, Shanghai Academy of Global Governance and Area Studies was founded in Shanghai International Studies University. These institutions set up a high-level platform for overseas ethnographic researches, and promote the further development of Chinese ethnology and anthropology. In fact, as early as the 1980s and 1990s, many universities and research institutions, such as Sun Yat-sen University, Institute of Ethnology and Anthropology of the Chinese Academy of Social Sciences (IEA-CASS), Xiamen University, Yunnan University and so on, started to encourage young scholars to go abroad, such as the United States, France, India, Japan, Vietnam, Malaysia, Thailand and other countries for overseas ethnographic researches, and have obtained abundant achievements. Therefore, the overseas ethnography today is the main force for academic output of Chinese anthropology.

As to how to carry out overseas ethnographic researches, Ma Guoqing holds that before carrying out overseas ethnography researches, we should clarify this question from four aspects: firstly, overseas research, as a way to understand the world, should be carried out according to China's own understanding. Secondly, we should unite China and the rest of the world as a whole. For example, how should Chinese enterprises respond to the accusation of the so-called neocolonialism in Africa by some Western countries? Thirdly, to study the world from the perspective of Chinese people. Fourthly, overseas researches should emphasize the organic connection between Western countries and China, such as how to understand the concept of "cultural China" from the perspective of anthropology? His answer to the question is the concept of "cross regional social system (Ma 2016)." Similarly, Wang Mingming put forward the theory of "three circles (Wang 2013)."

More importantly, the overseas ethnographic researches should have Chinese characteristics. Although there is no consensus on overseas ethnography at present, most of Chinese ethnologists and anthropologists generally reach an agreement that overseas ethnography is a new concept put forward by the Chinese ethnological and anthropological circle in the Chinese context. Therefore, Chinese overseas ethnographic studies should take a Chinese position different from the West to view and understand the outside world. According to Prof. Zhou Daming, the study object of overseas ethnographic is a foreign land, but should be discussed from the perspective of China's own cultural system and epistemological system (Zhou et al. 2018). Prof. Gao Bingzhong argues that Chinese anthropology should conduct "overseas ethnography" with Chinese characteristics. He upgrades Fei Xiaotong's "world society" put forward in 1940s as a supporting concept of overseas ethnography (Gao 2014). Prof. Wang Yanzhong also believes that in order to highlight Chinese characteristics, overseas ethnographic studies in China, which is still in its infancy, should not only serve for political needs, but also carry out investigations in a down-to-earth way. As for research perspectives, 
both subjective and objective methods are necessary (Wang 2014). According to Prof. Hao Guoqiang, the practice of overseas ethnography with Chinese characteristics should be carried out from three aspects: dealing with theoretical presupposition and local interpretation from the conceptual level; managing field entry, field integration and field output from the practical operation level; and establishing the theoretical guidance and writing principles of overseas ethnography from the theoretical level that adheres to the following principles: the "other" as the center, the reflection as the direction, the present as the basis, and the ordinary people as the research object (Hao 2014).

\section{International conferences}

The 16th World Congress of the International Union of Anthropological and Ethnological was successfully held in Kunming from July 27th to 31st, 2009. This is the largest and most important international conference ever held by the Chinese anthropological community. From the perspective of international cooperation, this conference successfully completed a major international dialogue and cooperation between Chinese and international academic circles.

In recent years, the Chinese anthropological community has participated in international activities frequently on a larger scale. Taking the international academic conferences organized by the Chinese anthropological community alone or jointly as an example, from September 10th to 14th, 2012, in Naples, Italy, the China Union of Anthropological and Ethnological Social Sciences not only assisted the IUAES in organizing various conferences, but also held a separate international conference on "Discussion on Sustainable Development: Urbanization, Industrialization and National Cultural Heritage in China." The participants were from 10 research institutions, including the United States, France, Germany, China, Italy and other five countries. In 2012, Prof. Peng Zhaorong, in cooperation with an American scholar, co-chaired a special conference on "Tourism and Ethnic Minorities in the Multicultural Society of East Asia," which was attended by 28 representatives of China and other countries; in the same year, Prof. He Ming co-chaired with a Singaporean scholar a special conference on "Dai People in the High Mountains of Southeast Asia and Asian Ethnography," which was attended by scholars from many countries. In 2012, Prof. Shilin and an American scholar jointly hosted the "Economic Category from the Perspective of Anthropology and Ethnology: Economic Anthropology and National Economics Symposium," and 28 Chinese and foreign scholars participated in the seminar (Huang et al. 2012).

From May 16th to 20th, 2015, the seminar on "Interphase Operational Theory ( 相际经营原理)" was jointly held by the Institute of Applied Anthropology of Jishou University and the Institute of Industrial and Commercial Anthropology of Shantou University in Jishou, Hunan Province, with the participation of scholars from China, the United States, Japan, India and other countries. This seminar shows that the "Interphase Operational Theory" put forward by Prof. Yang Tingshuo, a native Chinese anthropologist, has a wide influence in the international anthropological 
community, and has become an important contribution of Chinese anthropology to international anthropology.

On October 18th and 19th, 2015, the Chinese Social Science Forum: International Forum on the Innovation and Development of Ethnological and Anthropological Theories and Methods and The Academic Seminar Commemorating the 80th Anniversary of Mr. Fei Xiaotong's Dayaoshan Mountain Survey were held in Beijing. More than 80 experts and scholars from China, the United States, Japan, South Korea, Australia and other countries attended the forum. The forum focused on the topics of "innovation and development of ethnological and anthropological theories and methods," "cultural heritage and cultural consciousness," as well as "commemorating the 80th anniversary of Dayao Mountain Survey and remembering Mr. Fei Xiaotong," and so on. At this forum, most Chinese scholars presented the latest research results to foreign scholars, and garnered the latter's high appreciation and recognition.

From June 23rd to 24th, 2018, the College of Ethnology and Sociology and the Institute of Global Ethnology and Anthropology of Minzu University of China jointly hosted an international academic conference on "Global Encounter: China and the World from the Perspective of Transnational Mobility." Nearly 100 scholars from 19 countries attended the conference to discuss the phenomena, theories and methods of transnational and cross-border mobility.

From the above-mentioned international academic conferences held or attended by scholars at home and abroad, we can see that the Chinese anthropologists and ethnologists are cooperating extensively with their counterparts from more than 10 countries and regions, such as the United States, Canada, Singapore, the Netherlands, Japan, Australia, South Korea, France, Thailand, Spain, India, etc., and Chinese scholars have begun to actively participate in international dialogues and exchanges in a more and more confident manner, which creates favorable conditions and opportunities for Chinese academic circles to actively move towards the world.

\section{Conclusions}

It has been more than ten years since the 16th World Congress was successfully held in Kunming, China. Chinese anthropologists have been thinking about how to explore the new direction of anthropology during the transformation of China's economic and social structure. In order to cope with it, Chinese anthropologists should trace back and reflect on the essence of anthropology. In fact, many scholars, such as Murdoch, Qiao Jian, Fei Xiaotong, Li Yiyuan and so on, have pointed out the direction, which is to carry out interdisciplinary comprehensive researches and cross-cultural comparative researches. Following these two methods, Chinese anthropologists can continuously improve their comprehensive qualities, strengthen the team building of Chinese anthropology, and actively explore the "road of Chinese schools." 
Moreover, in order to explore the new direction of Chinese anthropology, contemporary Chinese anthropologists have been committed to making great efforts to improve three discipline abilities towards three directions to construct the discipline system of Chinese anthropology in the new era. Only in this way can Chinese anthropology adapt to the modern society, explain the current Chinese society, and become a prominent discipline of studying the contemporary society to avoid the crisis of the latent marginalization of Chinese anthropology.

Acknowledgements Not applicable.

Authors' contributions Shigang Liu conducts the research and writing. The author(s) read and approved the final manuscript.

Funding Not applicable.

Availability of data and materials Not applicable.

\section{Declarations}

Ethics approval and consent to participate Not applicable.

Consent for publication Not applicable.

Competing interests We have no competing interests.

Open Access This article is licensed under a Creative Commons Attribution 4.0 International License, which permits use, sharing, adaptation, distribution and reproduction in any medium or format, as long as you give appropriate credit to the original author(s) and the source, provide a link to the Creative Commons licence, and indicate if changes were made. The images or other third party material in this article are included in the article's Creative Commons licence, unless indicated otherwise in a credit line to the material. If material is not included in the article's Creative Commons licence and your intended use is not permitted by statutory regulation or exceeds the permitted use, you will need to obtain permission directly from the copyright holder. To view a copy of this licence, visit http://creativecommons.org/licen ses/by/4.0/.

\section{References}

Tonnies, F. 1957. Gemeinschaft und Gesellschaft (Community and Society), translated and edited by Charles P. Loomis: The Michigan State University Press.

Durkheim, E. 1997. The division of labour in society (French: De la division du travail social). Translated by W. D. Halls. New York: Free Press.

Fang, Lili (方李莉), 2000. Tradition and change: a field study of old and new Kilns in Jingdezhen (《传 统与变迁一一景德镇新旧民窑田野考察》). Jiangxi: Jiangxi People's Publishing House (江西人 民出版社).

Fei, Xiaotong (费孝通), 1948. From the soil: The Foundations of Chinese Society (First Edition) (《乡土 中国》). Shanghai: Shanghai Observatory Press (上海观察设初版本).

Fei, Xiaotong (费孝通). 1983. Practice and investigation: a discussion on the development of towns (《 行行重行行: 乡镇发展论述》). Yinchuan: Ningxia People's Publishing House (宁夏人民出版社). 
Fei, Xiaotong (费孝通). 1989. The pattern of pluralistic integration of the Chinese nation (中华民族多元 一体格局). Journal of Peking University (Philosophy and Social Sciences) (《北京大学学报》(哲 学社会科学版)). (4): 1-19.

Fei, Xiaotong (费孝通). 1992. Recognition of the Pearl River model (珠江模式的再认识). Outlook (《 瞭望》). (27):34-39.

Fei, Xiaotong (费孝通). 1997. Reflections, dialogues and consciousness of culture (反思·对话·文化自 觉). Journal of Peking University (Philosophy and Social Sciences) (《北京大学学报》 (哲学社会 科学版)). (3): 15-23.

Fei, Xiaotong (费孝通). 2001. Peasant life in China (《江村经济》). Beijing: The Commercial Press ( 商务印书馆).

Hao, Guoqiang (郝国强). 2014. Reflections on the study of Chinese overseas ethnography in recent 10 years (近10年来中国海外民族志硎究反观). The Ideological Front (《思想战线》). 40(5): 57-64.

He, Xingliang (何星亮). 1998. Social sciences in the west and anthropology and ethnology in China: An interview with Professor Li Yiyuan (西方社会科学与中国人类学、民族学㸴究——李亦园教 授访谈录). The Ideological Front (《思想战线》). (9): 85-88.

He, Xingliang (何星亮). 1982. Looking at the Oldest Kinship System from the Kinship Terms of Kazak People, Kirgiz People and Han People (从哈、柯、汉亲属称谓看最古老的亲属制度). EthnoNational Studies (《民族㸴究》). (3): 67-77.

He, Xingliang (何星亮). 2018. The belt and road initiative and the community with shared future for humankind (“一带一路”建设与人类命运共同体). Journal of South-Central University for Nationalities (Humanities and Social Sciences) (《中南民族大学学报》 (人文社会科学版)). 38(4):116-122.

$\mathrm{He}$, Xingliang (何星亮). 2000. On the localization and internationalization of anthropology (论人类学的 本土化与国际化). Journal for Guangxi Institute of Nationalities (Philosophy and Social Sciences Edition) (《广西民族学院学报》((哲学叔会科学版)). (2):115-121.

Huang, Zhongcai (黄忠彩) and Zhang, Jijiao (张继焦). 2012. The fruitful achievements of the world's grand meeting: an overview of the latest academic achievements of the 16th Congress of the International Union of Anthropological and Ethnological Sciences (世界的盛会 丰硕的成果一一国际 人类学与民族学联合会第十六届大会最新学术成果概述). Beijing: Intellectual Property Press ( 知识产权出版社).

Gao, Bingzhong (高丙中). 2014. Overseas ethnography and world society (海外民族志与世界性社会). World Ethno-National Studies (《世界民族硎究》)(1):50-53.

Geller (格勒). 2012. Some thoughts on the service of Chinese anthropological research to reality (关于中 国人类学㸴究为现实服务的几点思考). Journal of Southwest Minzu University (Humanities and Social Sciences Edition) (《西南民族大学学报》(人文社会科学版)). (4): 1-5.

Li, Cui (李翠). 2017. Urban anthropology: the “urban school” of ethnology and anthropology (都市人类学: 民族学人类学的 “城市学派”). China Ethnic News (《中国民族报》), June $23^{\text {rd }}$.

Li, Shaoming (李绍明). 2007. Several problems in the study of Tibetan-Yi Corridor (藏彝走廊㗏究中的几 个问题). Journal of Southwest Minzu University (Humanities and Social Sciences Edition) (《西南民 族大学学报》(人文社科版)). 185(1): 14-17.

Li, Yiyuan (李亦园). 2013. Culture and cultivation (《文化与修养》). Beijing: Jiuzhou Press (九州出版 社).

Ma, Guoqing (麻国庆). 2016. The intra-regional social system: cases from the silk road around the South China Sea Rim (跨区域社会体系: 以环南中国海区域为中心的丝绸之路硎究). Ethno-National Studies (《民族㗏究》). (3): 41-54.

Ma, Guoqing (麻国庆). 2017. Firmly establishing the consciousness of the community for Chinese nation for ethnic studies in the new era (《民族硎究的新时代与铸牢中华民族共同体意识》). Journal of Minzu University of China (Philosophy and Social Sciences Edition) (《中央民族大学学报》 (哲学 社会科学版)). 44(6): 21-27.

Nakane Chie. 1994. Interpersonal relationship in vertical society. Translated by Chen Cheng \& Dong Er, Beijing: The Commercial Press.

Naran, Bilik (纳日碧力戈). 1996. Monologue and dialogue in Chinese anthropology: topics and problems ( 中国人类学的独白和对白: 课题与问题). Journal of Guangxi Institute for Nationalities (Philosophy and Social Sciences Edition) (《广西民族学院学报》 (哲学社会科学版)). (2):89-95.

Peng, Zhaorong (彭兆荣). 2012. “Chinese paradigm” of intangible cultural heritage system (非物质文化遗 产体系的“中国范式”). Guangming Daily (《光明日报》), June 6th, No.11. 
Qiao, Jian (乔健). 1995. The predicaments and prospects of the development of anthropology in China (中 国人类学发展的困境与前景). Journal of Guangxi Institute for Nationalities (Philosophy and Social Sciences Edition) (《广西民族学院学报》(哲学社会科学版)), No.1, pp.15-20.

Qiao, Jian (乔健). 2002. The bottom society: a new concept to study Chinese society (底边社会一一个 对中国社会㗑究的新概念). Northwestern Journal of Ethnology (《西北民族研究》). 20(1): 25-31.

Qiao, Jian (乔健) and Xu, Jieshun (徐杰舜). 2013. Dialogue: Qiao Jian and Chinese anthropology (对话:乔 健与中国人类学). Qinghai Journal of Ethnology (《青海民族㸴究》). 24(2): 1-10.

Qu, Mingan (篗明安). 2014. The theories of symbolic anthropology (《象征人类学理论》). Beijing: People's Publishing House (人民出版社).

Timur (铁木尔) and Shen, Lin (沈林). 2000. The 21st century: the century of anthropology and ethnology (21世纪: 人类学民族学的世纪). Chinese Nation (《中国民族》). (11):42-46.

Wang, Yanzhong (王延中). 2014. Great achievements in overseas ethnography (海外民族志砰究大有可 为). World Ethno-National Studies (《世界民族㸴究》). (1):53-58.

Wang, Yanzhong (王延中). 2018. Creating a strong sense of community for the Chinese nation and its building (铸牢中华民族共同体意识, 建设中华民族共同体). Ethno-National Studies (《民族㸴究》). (1): $1-9$.

Wan, Fubin (万辅涁), Wei Danfang (韦丹芳) and Meng Zhenxing (孟振兴). 2011. Traditional crafts from the perspective of anthropology (《人类学视野下的传统工艺》). Beijing: People's Publishing House (人民出版社).

Wang, Mingming (王铭铭). 2013. “Three circles”: Another world view, another social science (三圈 说一一另一种世界观, 另一种社会科学). Northwestern Journal of Ethnology (《西北民族㸴究》). 76(1):82-99.

Wang, Mingming (王铭铭). 2007. The Tibetan-Yi corridor-a multidisciplinary regional research (藏彝走 廊——多学科区域研究). Journal of Southwest Minzu University (Humanities and Social Sciences) ( 《西南民族大学学报》(人文社科版)). 185(1): 20-21.

Wu, Xiaohua (乌小花)and Ai, Yisi (艾易斯). 2018. The “belt and road” between the community for Chinese nation and the community with shared future for mankind: concept, value and realization path ("一带 一路”在中华民族共同体与人类命运共同体之间: 理念、价值与实现路径). Northwestern Journal of Ethnology (《西北民族硎究》). 99(4):21-29.

Xu, Jieshun (徐杰舜). 1999. Snowball: an anthropological analysis of the Han nationality (《雪球: 汉民族 的人类学分析》). Shanghai: Shanghai People’s Publishing House (上海人民出版社).

Xu, Jieshun (徐杰舜). 2010. The Chinese rural school of anthropological studies-in connection with the centennial of Mr. Fei Xiaotong and Mr. Lin Yaohua (人类学中国乡村学派初论一一费孝通林耀 华百年诞辰谈起). Academic Exploration (《学术探索》). (6):71-78.

Xu, Jieshun (徐杰舜)\& Liu, Bingqing (刘冰清), 2012. Rural anthropology (《乡村人类学》). Yinchuan: Ningxia People's Publishing House (宁夏人民出版社).

Xu, Jieshun (徐杰舜), Zhao, Xundong (赵旭东), et al. 2018. Anthropology encounters cultural transformation (人类学遭遇文化转型). Journal of Original Ecological National Culture (《原生态民族文化学 刊》). 10(1): 1-11.

Xu, Lili (徐黎丽). 2017. Corridor belt theory - an exploration study of Chinese frontier governance theory (通道地带理论一一中国边疆治理理论初探). The Ideological Front (《思想战线》). 43(2): 67-75.

Yang, Tingshuo (杨庭硕). 1995. Interphase (Xiangji) operational theory (《相际经营原理》). Guizhou: Guizhou Ethnic Publishing House (贵州民族出版社).

Zhang, Jijiao (张继焦). 2004. The "differential mode of association": from rural to urban version一with examples of the migrants' urban employment (差序格局从“乡村版”到“城市版”一一以迁移者的城 市就业为例). Ethno-National Studies (《民族㸴究》). (6): 50-61.

Zhang, Jijiao (张继焦) (ed). 2015. A new round of urbanization, industrialization, marketization, and cultural diversity: a discussion on globalization and modernization (《新一轮城市化、工业化、市场 化、文化多元化一对全球化和现代化的探讨》). Beijing: Intellectual Property Publishing House (知识产权出版戚).

Zhang, Jijiao (张继焦). 2016a. The paradigm transition of anthropology and ethnology: from "pattern of differential sequence" to “transformation of social structure” (人类学民族学㸴究范式的转变: 从 “差序 格局”到 “社会结构转型”). Journal of Northwest Normal University (Social Sciences) (《西北师大 学报》(社会科学版)). 53(3): 5-14.

Zhang, Jijiao (张继焦). 2016b. The "umbrella society": A new concept for observing social-economic structural transition in China. International Journal of Business Anthropology (by Cambridge Scholars Publishing). 6(2):83-102 
Zhang, Jijiao (张继焦). 2016c. Out of the predicament of research paradigm: a four-level analysis approach of enterprise anthropology (走出研究范式的困境: 企业人类学的 “四层次分析法” ) (《广西民族 大学学报》 (哲学社会科学版)). 38(6): 92-100.

Zhang, Jijiao (张继焦). 2017a. The latest trend of Chinese anthropology and ethnology: walking out of villages centered on old and famous enterprise, towards modernization (中国人类学民族学的最新趋 势: 走出村落, 以老字号为抓手, 走向现代化). Qinghai Journal of Ethnology (《青海民族研究》). 28(2): 39-44.

Zhang, Jijiao (张继焦). 2017b. From "cultural consciousness" to "cultural confidence": the historical turn of Chinese cultural thought (从 “文化自觉”到 “文化自信”: 中国文化思想的历史性转向). The Ideological Front (《思想战线》) 43(6): 9-16.

Zhang, Jijiao (张继焦). 2018. Beehive society: a new concept for observing China's social- economic transformation. International Journal of Anthropology and Ethnology, by Springer.

Zhang, Jijiao (张继焦)\& Song, Dan (宋丹). 2018. Urban anthropology: "urban school” of ethnology and anthropology: an interview with Professor Zhang Jijiao (都市人类学: 人类学民族学的 “城市学 派”一一访中国人类学民族学硎究会都市人类学委员会主席张继焦教授). Journal of Guangxi Teachers Education University (Philosophy and Social Sciences Edition) ( 《广西师范学院学报》 (哲 学社会科学版)) 39(3): 98-106.

Zhao, Xudong (赵旭东) and Dan, Huiling (单慧玲). 2017. The prospect of Chinese ethnic corridor study: from the "Tibetan Yi Corridor" to the "belt and road initiative" of the world (中国走廊发凡一从民 族的“藏彝走廊”到世界的“一带一路”). The Ideological Front ( 《思想战线》) 43(2):112-119.

Zhou, Daming (周大鸣). 2000. Migrant labor and the “dual community” in the Pearl River delta (外来工与 “二元社区”一珠江三角洲的考察). Journal of Sun Yat-sen University (Social Sciences Edition) (《 中山大学学报》 (社会科学版)) 40(4): 107-112.

Zhou, Daming (周大鸣)and Gong, Xia (龚霞). 2018. Overseas research: a new trend in the development of Chinese anthropology (海外㸴究: 中国人类学的新发展趋势). Journal of Guangxi University for Nationalities (Philosophy and Social Sciences Edition) (《广西民族大学学报》(哲学社会科学版)) 40(1):116-123.

Zhou, Daming (周大鸣), Guo, Yongping (郭永平) and Wang, Zhenzhen (王真真). 2015. Loess civilization Jiexiu Model: Academic Consciousness and Cultural Consciousness of Anthropology in China ( 黄土文明.介休范例——中国人类学的学术自觉与文化自觉). Journal of Guangxi University for Nationalities (Philosophy and Social Sciences Edition) (《广西民族大学学报》 (哲学社会科学版)) 37(3):2-8.

Zhou, Daming (周大鸣) and Zhang, Chao (张超). 2018. An analysis of historical and contemporary significance of ethnical corridor study (如何理解中国: 民族走廊硎究的历史与现实意义). Social Sciences Front (《社会科学战线》) (12): 1-8.

Zhou, Jianxin (周建新). 2006. Controversy and practice of historical anthropology in China: a case study on South China School (历史人类学在中国的论争与实践——以华南硎究为例). Inner Mongolia Social Sciences (Chinese Edition) (《内蒙古社会科学》) 37(3): 83-86.

Zhuang, Kong Shao (庄孔韶) and Lan, Linyou (兰林友). 2009. Anthropology in China: the present and prospect (我国人类学硎究的现状与前瞻). Journal of Renmin University of China (《中国人民大学 学报》) (3):144-150.

\section{Comments}

Publisher's Note Springer Nature remains neutral with regard to jurisdictional claims in published maps and institutional affiliations. 